„Bohemistyka” 2020, nr 2, ISSN 1642-9893

Milena HeBAL-JEZIERSKA

DOI: $10.14746 /$ bo.2020.2.4

Uniwersytet Warszawski

\title{
Formy imienne przymiotników twardotematowych we współczesnym języku czeskim - analiza korpusowa
}

Keywords: short forms of hard-stem adjectives, Czech language, corpus analysis

Słowa kluczowe: przymiotniki twardotematowe imienne, język czeski, analiza korpusowa

\section{Abstract}

The aim of the article is to analyze short forms of adjectives in Czech in the context of their long equivalents. The research material was collected from the corpus of the Czech language, SYN2015. Native adjectives are statistically on the margins of the Czech language. They appear in specific grammar and lexical constructions. Therefore, they occupy a permanent place in the Czech system. They are used not only in literary statements, as the Czech grammar shows, but also in colloquial literary language (e.g. a hotovo). The short forms of adjectives most often perform the function of a predicate or predicative, more rarely an incongruent attribute, adverbial or independent element. Some adjectives occur in established language connections (e.g. pokud možno, bud' tak laskav, bud' zdráv).

Celem artykułu jest analiza form krótkich przymiotników w języku czeskim w kontekście ich złożonych odpowiedników. Materiał badawczy został zebrany z równoważnego korpusu języka czeskiego SYN2015. Przymiotniki imienne znajduja się pod względem statystycznym na marginesie języka czeskiego. Występują w konkretnych konstrukcjach gramatycznych i leksykalnych. Zajmują zatem stałe miejsce w systemie czeszczyzny. Sa stosowane w wypowiedziach literackich, nie tylko książkowych, jak wskazują na to gramatyki języka czeskiego, ale nieraz także w potocznym języku literackim (np. a hotovo). Przymiotniki imienne najczęściej pełnią funkcję orzecznika lub predykatywu, rzadziej okolicznika, przydawki niekongruentnej lub członu samodzielnego. Część przymiotników imiennych występuje w ustalonych połączeniach językowych (np. pokud možno, bud' tak laskav, bud'zdráv). 
We współczesnym języku czeskim wyróżnia się przymiotniki twardo- i miękkotematowe. Przymiotniki twardotematowe mogą przybierać formy krótkie (imienne, proste) oraz postacie długie (zaimkowe, złożone), przymiotniki miękkotematowe - wyłącznie formy długie. Postacie krótkie są tożsame z końcówkami rzeczownika, stąd ich nazwa imienne (Damborský 1970). W niniejszym artykule zostaną poddane analizie formy krótkie przymiotników w języku czeskim w kontekście ich złożonych odpowiedników. Materiał badawczy został zebrany z równoważnego korpusu języka czeskiego SYN2015. W uzasadnionych przypadkach poświadczenia były zbierane również z innych korpusów. Wyniki zostały zweryfikowane na materiale pozostałych korpusów zrównoważonych.

\section{Zarys historyczny}

Formy krótkie przymiotników są pozostałością deklinacji rzeczownej, która po względem chronologicznym pojawiła się pierwsza. Według tej odmiany odmieniały się rzeczowniki, przymiotniki i niektóre liczebniki. Pozostałości tego stanu są obecne do dziś. Deklinacja przymiotna złożona, powstała na skutek przyłączenia do form rzeczownikowych postaci zaimka anaforycznego $*_{\mathrm{j} b}, *_{\mathrm{ja}}$, *je (Bartula 1997, s. 62). Miało to jednak miejsce później.

Korzeni tej sytuacji należy szukać już w języku prasłowiańskim. Bartula (1997, s. 61), omawiając odmianę przymiotników w języku staro-cerkiewno-słowiańskim, twierdzi, że ,język scs. odziedziczył na równi z innymi językami słowiańskimi z języka prasłowiańskiego dwa typy odmiany przymiotników - niezłożoną (prosta), czyli rzeczownikową, i złożoną, inaczej, tzw. zaimkową" (Bartula 1997, s. 62). Wówczas zasięg form krótkich przymiotników był o wiele szerszy. Odmieniały się tak zarówno przymiotniki, z dzisiejszego punktu widzenia określane jako, twardo- i miękkotematowe. Ich formy nie były ograniczone do konkretnych przypadków. Stosowało się je w funkcji orzecznikowej i przydawkowej.
Odmiana rzeczowna przymiotników była stopniowo wypierana przez deklinację złożoną. Już we wczesnym rozwoju czeszczyzny formy krótkie przymiotników, dziś określanych jako miękkotematowe, były uważane za archaiczne (Lamprecht, Šlosar, Bauer 1986). Stopniowo zatem zostały wyparte. Natomiast przymiotniki twardotematowe ostały się na marginesie języka czeskiego, wypierane przez deklinację złożoną (zaimkową). Przyczyny tej sytuacji upatrują autorzy wspomnianej gramatyki historycznej w potrzebie rozróżnienia deklinacji przymiotnika od rzeczownika.

Odmiana rzeczowna w zależności od rdzenia zachowała się do tej pory w niektórych przymiotnikach oraz liczebnikach. Odnaleźć ją można we współczesnym języku czeskim w odmianie przymiotników dzierżawczych (Karlìv, Karlova, Karlovo), niektórych liczebników (čtvero), i zaimków, np. sám.

\section{Formy imienne przymiotników w gramatykach wspólczesnego języka czeskiego}

Odmiana imienna przymiotników zajmuje stałe miejsce w opisach zamieszczanych w gramatykach języka czeskiego. Nie są to jednak dogłębne analizy tego zjawiska $\mathrm{z}$ wyjątkiem opisu zawartego w tzw. gramatyce akademickiej (Mluvnice češtiny 1986), który jednak trudno uważać za aktualny. W zależności od publikacji podkreślane są różne aspekty przymiotników imiennych. W tej części artykułu podsumowuję informacje zawarte w czeskich gramatykach dotyczących tego tematu. Z porównania opisów gramatycznych rzuca się w oczy problem klasyfikacyjny. Dotyczy on niektórych form rodzaju nijakiego, które można postrzegać jako szczególny rodzaj przysłówków, np. smutno, veselo, možno, nutno (np. Nekula, Rusínová, Grepl, Karlík 1995). Do tej listy dopisywany jest niekiedy wyraz schopno. Kovář́ková (2010, s. 201) twierdzi jednak, że możliwość wymiany końcówki -o na -é w cytowanych słowach przesądza o klasyfikacji przymiotnikowej. Podobnie jedyny przymiotnik rád mający wyłącznie odmianę rzeczowną, jest określany niejednoznacznie, a zatem jako przy- 
miotnik pełniący niekiedy również funkcję przysłówka. W korpusowej gramatyce pod redakcją V. Cvrčka, w rozdziale poświęconym przymiotnikom, Kováŕíková (2010, s. 201) zalicza do tej części mowy również leksem sám (w odróżnieniu od połączenia językowego ten samý, który jest tu klasyfikowany jako przymiotnik). Choć dla polskiego językoznawcy taka kategoryzacja może nie być zaskoczeniem, z punktu widzenia bohemisty, jest to informacja nowa. Leksem sám jest bowiem w większości czeskich gramatyk klasyfikowany jako zaimek.

W opisach form imiennych przymiotników są również rozpatrywane nastepujace kwestie: rodzaj przymiotników przyjmujących postać krótką, ich relacja w stosunku do form długich, paradygmat postaci imiennych, ich kwalifikacja stylistyczna. Formy imienne przybierają współcześnie wyłącznie przymiotniki twardotematowe, jakościowe (Mluvnice češtiny 1986), ich rdzeń jest najczęściej zakończony $-n,-v$, - $t$ (Kováŕíková 2010). Postacie krótkie mają obecnie paradygmat defektywny; zachowały sie przede wszystkim w mianowniku. Formy biernikowe, które również można odnaleźć w czeszczyźnie, są określane przez niektóre publikacje jako archaiczne, np. Nekula, Rusínová, Grepl, Karlík 2012, s. 282). W większości przypadków, z wyjątkiem mianownika liczby pojedynczej rodzaju nijakiego: možno, nutno, przymiotniki imienne odnoszą się do osób (Kovář́lková 2010, s. 201; Damborský 1970; Mluvnice češtiny 1986). W publikacji Mluvnice češtiny są zawarte przykłady obrazujące to zjawisko:

Je ještě mlád (użycie formy krótkiej) $\neq$ Ten strom je mladý (użycie formy długiej).

Otec je nemocen $\neq$ Ten strom je nemocný.

Bratr je již stár. $\neq$ Ten strom je již starý.

Byl pln černých myšlenek $\neq$ Džbán byl plný malin.

W danych korpusowych znajdziemy jednak sporadyczne przypadki użycia form krótkich i w kontekstach nieosobowych (patrz dalej).

Formy krótkie przymiotników nie są ograniczone leksykalnie w takim stopniu jak w polszczyźnie, w której wyróżnia się zaledwie około
20 przymiotników (Bańko 2002). W publikacjach dotyczących czeszczyzny brakuje informacji o liczbie przymiotników imiennych. Wyjątkiem jest gramatyka korpusowa pod redakcją Cvrčka. Autorka rozdziału poświęconego temu zjawisku, Dominika Kováŕíková, twierdzi, że jest ich ok. 60. W większości publikacji natomiast podkreśla się, że zakres występowania form krótkich jest węższy niż długich. Jest on ograniczony nie tylko liczbą przypadków, w których pojawiaja się, ale także formami rodzajowymi. W publikacji Mluvnice češtiny twierdzi się, że najstabilniejsza jest forma krótka mianownika rodzaju męskiego. Wystąpienia przymiotników imiennych przybierających inne końcówki rodzajowe zdarzają się o wiele rzadziej.

W tej samej publikacji można zaleźć również stwierdzenie, że krótkie formy uważane są za wariantywne postaci długich. Są nieproduktywne oraz należą do pozostałości historycznych. Nie wszystkie przymiotniki przybieraja jednak obie postacie. O ile każda krótka forma ma odpowiednik długi (z wyjątkiem leksemu rád), to nie każda długa postać ma odpowiednik krótki. Postacie imienne nie sa poświadczone u przymiotników na -rý (dobrý), na -cký (dělnický), na -ský (český) apod. (Mluvnice češtiny 1986, s. 75).

Ograniczenia w dystrybucji form imiennych można także zauważyć przy analizie funkcji składniowych, w których występują. Wymienia się tu przede wszystkim funkcję predykatywu i orzecznika (np. Mluvnice češtiny 1986).

O istotnych różnicach znaczeniowych traktuje również Mluvnice češtiny (1986, s. 75). Jest to temat pomijany w wielu publikacjach, a jednak niezmiernie ważny. Przykłady zawarte w cytowanej publikacji zamieszczam poniżej:

jistý $\neq$ jist (pewny $\neq$ pewien)

měl jistou $r u k u \neq$ byl si tím jist (miał pewną ręką $\neq$ był tego pewien)

hodný $\neq$ hoden (grzeczny $\neq$ godzien)

hodný člověk $\neq$ být hoden úcty (grzeczny, dobrze wychowany $\neq$ byt godzien szacunku/czci)

hotový $\neq$ hotov (gotowy $\neq$ gotów)

hotový oblek $\neq$ byl hotov zemřít (gotowy garnitur $\neq$ byt gotów umrzé́) 
prostý $\neq$ prost (prosty $\neq$ pozbawiony)

prostý život $\neq$ prost viny (proste życie $\neq$ pozbawiony winy)

mocný $\neq$ mocen (mocný pán $\neq$ nebyl mocen slova).

Ostatnia kwestia poruszana w pulikacjach dotyczących przymiotników krótkich, to ich kwalifikacja stylistyczna. Pod tym względem przymiotniki imienne są uważane za nacechowane. Stylistika současné češtiny (Čechová, Chloupek, Krčmová, Minářová 1997, s. 93): określa większość z nich jako książkowe, a ich zastosowanie nie jest według autorów tej publikacji neutralne. Ponadto formy te są charakterystyczne dla języka urzędowego (Čechová, Chloupek, Krčmová, Minářová 1997; Nekula, Rusínová, Grepl... 2012, s. 282), co potwierdza ich nacechowanie. W niektórych publikacjach zwraca się uwage na to, że niektóre przymiotniki krótkie są charakterystyczne dla konkretnych połączeń połączeń językowych (Čechová, Chloupek, Krčmová, Minářová 1997; Nekula, Rusínová, Grepl, Karlík 2012, s. 282). Za neutralne uważają autorzy publikacji Př́ruční mluvnice (2012) bud' zdráv, jsme rádi.

Jak jednak wykaże analiza korpusowa, kwestia kwalifikacji stylistycznej jest sprawą złożoną i zależną od konkretnych przymiotników.

\section{Analiza korpusowa}

Jak już wspomniałam we wstepie, analiza przymiotników imiennych została przeprowadzona na podstawie danych zebranych z korpusu referencyjnego SYN2015. Niektóre wyniki jednak są weryfikowane na podstawie materiału uzyskanego $\mathrm{z}$ innych korpusów. W badaniu przyjęto tradycyjną czeską klasyfikację części mowy ze względu na kilka kwestii. Przymiotniki sa w korpusie znakowane według tradycyjnego podziału. Taka właśnie klasyfikacja dominuje w czeskiej literaturze przedmiotu, co pozwala na porównanie istniejących opisów z materiałem korpusowym.

\section{Dane frekwencyjne w świetle danych korpusowych}

Z danych zawartych w korpusach referencyjnych Czeskiego Korpusu Narodowego (dalej CzNK) poświadczenia przymiotników imiennych stanowią zaledwie jeden procent form przymiotników. Prawie połowę potwierdzeń, $47 \%$, stanowią poświadczenia leksemu rád, klasyfikowanego przez większość czeskich językoznawców jako jedyny przymiotnik krótki. Pozostałe potwierdzenia stanowią tylko $0,5 \%$ poświadczeń przymiotników.

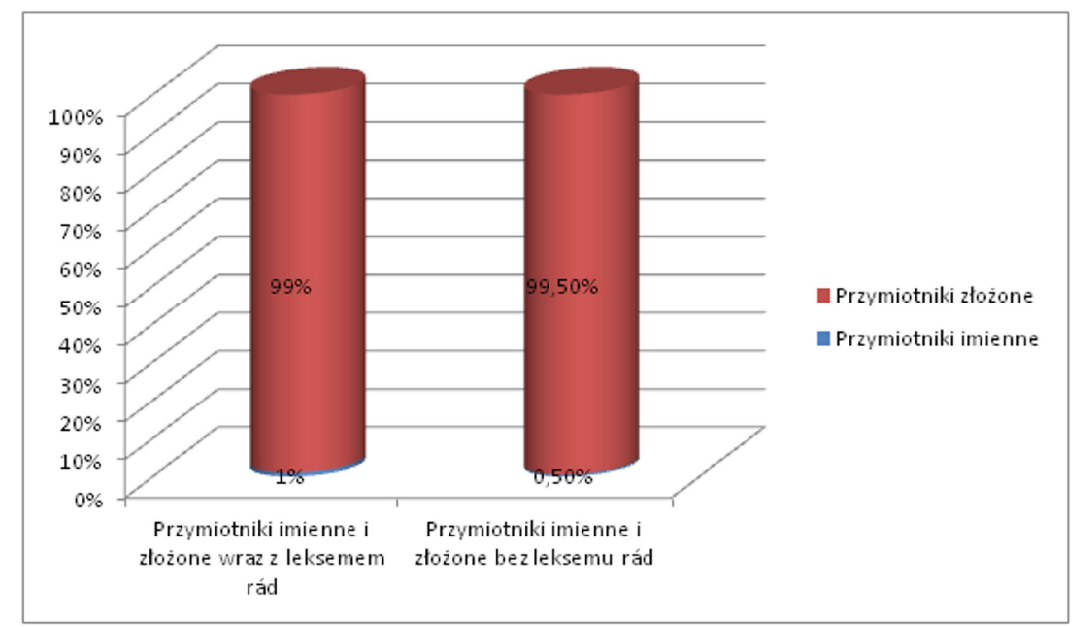

Rysunek 1. Udział form imiennych i złożonych w populacji przymiotników (na podstawie danych uzyskanych z korpusu Syn2015)

Dane frekwencyjne pokazują również, które z przymiotników są częściej od innych stosowane właśnie w formach imiennych. Jak już wcześniej wspomniałam, najwyższą frekwencją cieszy się przymiotnik rád, który odmienia się rzeczownie. U pozostałych przymiotników mamy do czynienia $\mathrm{z}$ wariantywnością postaci złożonych i imiennych ${ }^{1}$. U większości przymiotników dominuje odmiana złożo-

\footnotetext{
${ }^{1}$ Wariantywność obu form nie dotyczy wszystkich przymiotników.
} 
na. Przymiotniki, w których to forma krótka jest częstsza od długiej to: schopen/schopný, ochoten/ochotný. Przymiotniki dlužen/dlužný, spjat/spjatý mają częściej występującą formę krótszą w korpusach referencyjnych, w korpusach publicystycznych natomiast dominuje postać długa.

Przykłady przymiotników, w których została zarejestrowana postać imienna : rád, schopný, možný, známý, nutný, ochotný, spokojený, vědomý, jistý, pritomný, hotový, povinný, rovný, spjatý, vinný, mrtvý, plný, hodný, zdravý, št'astný, dlužný, živý, bosý, patrný, zvědavý, podobný, vděčný, laskavý, věrný, čistý, nápomocný, osamocený, prostý, nemocný, svobodný, bezpečný, starý, mladý.

Szczegółowa analiza korpusowa wykazała, że problematyka dystrybucji postaci krótkich jest bardzo skomplikowana, zależna od konkretnego przymiotnika, a nieraz i typu tekstu. Dane statystyczne pokazują bardzo ogólny obraz, który jest wypadkową kilku często występujących przymiotników. W swojej analizie uwzględniam jednak również te przymiotniki, które zachowują się zupełnie inaczej, niż wskazywałaby statystyka. Przymiotniki imienne są bardzo zróżnicowaną grupą. Ich cechami wspólnymi jest najczęściej jednak ograniczenie stosowania dotyczące przede wszystkim łączliwości, konstrukcji gramatycznych, w których występują oraz form fleksyjnych.

\section{Fleksja przymiotników imiennych w świetle danych korpusowych}

Wszystkie przymiotniki imienne są defektywne pod względem odmiany. Występują właściwie tylko w mianowniku. Poświadczenia form biernikowych należą do sporadycznych.

Są również pozbawione kategorii stopnia. Częściowe ograniczenia można również zaobserwować w łączeniu się form krótkich $\mathrm{z}$ wykładnikami kategorii rodzaju, choć tu sytuacja jest o wiele bardziej zróżnicowana i zależna od konkretnych przymiotników. Najczęściej występują one w formie rodzaju męskiego lub w rodzaju nijakim (np. zdráv, živ, nutno, možno). Wśród przymiotników krótkich są jednak przymiotniki, które nie mają form rodzaju męskiego. Należą do nich, np. przymiotniki z sufiksem -ný, tj. možný, nutný, patrný. Tutaj także można zaobserwować zróżnicowanie pod względem przybierana form rodzajowych. Przymiotnik patrný ma w porównaniu z przymiotnikami možný, nutný większy wachlarz możliwości, np. patrno, patrna, patrny.

Wśród przymiotników krótkich można również wyróżnić sporą grupę występującą we wszystkich formach rodzajowych bez zmiany nacechowania stylistycznego. Tutaj należą przymiotniki, które na liście frekwencyjnej zajmują wysokie pozycje, np. schopný, známý, ochotný, spokojený, vědomý, jistý, přitomný, hotový, povinný, rovný, spjatý, vinný, mrtvý, plný, hodný, št'astný, dlužný, zvědavý, podobný, vděčný, laskavý, věrný.

W danych korpusowych znajdują się również poświadczenia postaci krótkich występujących w kontekstach nieosobowych, co nie jest zgodne z opisami znalezionymi w gramatykach. Są to sporadyczne potwierdzenia. Mogą świadczyć o niewiedzy autorów, jak powinny być stosowane przymiotniki imienne w tekście.

Zlato bývá na těchto ložiskách př́itomno jako ryzí (někdy jde o zlato s vysokým podílem stříbra - tzv. elektrum) nebo jako příměs v sulfidech (hlavně $\mathrm{v}$ arzenopyritu a pyritu), méně často je zlato vázáno na teluridy. Zimák, Jiří (2013): Ložiska nerostných surovin. Olomouc: Univerzita Palackého.

Náš obraz vývoje vesmíru umíme prodloužit do doby, kdy byl vesmír stár pouhou jednu sekundu. Krauss, Lawrence Maxwell (2013): Vesmír z ničeho. Překlad: Langer, Jiří. Praha: Knižní klub.

\section{Występowanie form imiennych i zlożonych w tekstach w świetle danych korpusowych}

Analiza występowania w tekstach postaci krótkich i długich uwzględnia zarówno ich dystrybucję w populacji przymiotników złożonych i imiennych, jak i ich udział w poszczególnych typach tekstów. We wszystkich rodzajach tekstów (publicystyka, beletrystyka, literatura specjalistyczna) formy krótkie są formami marginalnymi (por. rys. 2). 
Rozłożenie form długich i krótkich w poszczególnych rodzajach tekstów nie przekracza nawet jednego procenta.

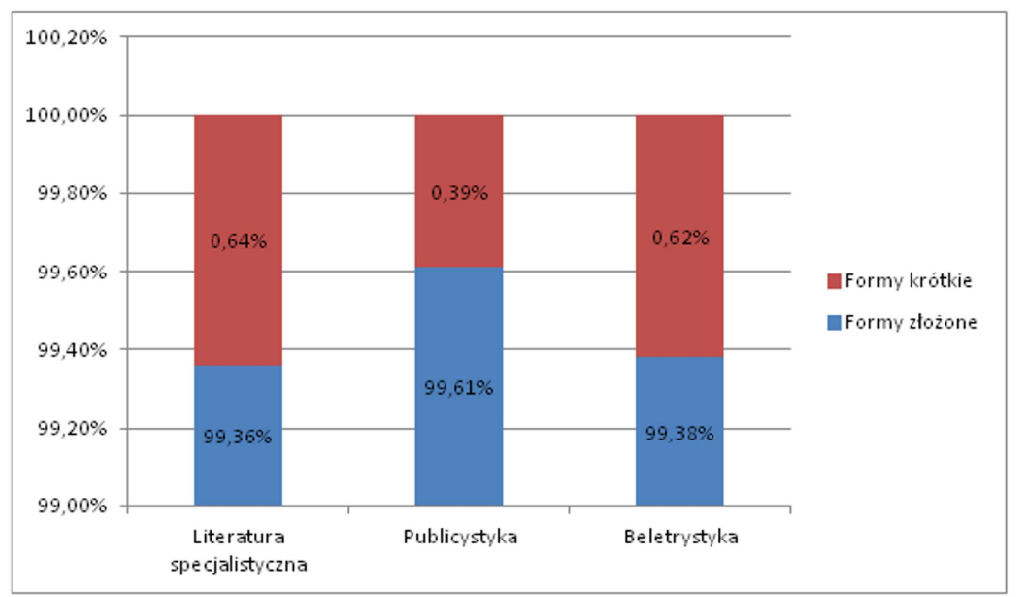

Rysunek 2. Występowanie form imiennych oraz złożonych w tekstach

Obydwie formy są charakterystyczne dla literatury specjalistycznej, o czym nie pisze się w publikacjach. W populacji postaci imiennych jest ona reprezentowana nieznacznie lepiej (49\%), niż ma to miejsce w grupie form zaimkowych (42\%). Różnica wynosi zaledwie 7 punktów procentowych (por. rys. 3 i 4). Podobnie niewielka rozbieżność jest widoczna w rozłożeniu omawianych form w beletrystyce. Wśród przymiotników krótkich beletrystyka zajmuje 26 procent, wśród długich - odrobinę mniej - 22\%. Największe zróżnicowanie jest obserwowalne w publicystyce. Dystrybucja postaci imiennych wynosi tu 24 procent, natomiast przymiotników złożonych -35 procent. $\mathrm{Z}$ tego zestawienia wyłania się zatem dość skomplikowany obraz, z którego może wynikać duże zróżnicowanie tej grupy.

Szczegółowa analiza przymiotników imiennych wyróżniających się najwyższą frekwencją wykazała głębokie zróżnicowanie pod względem ich wysteppowania w tekstach. Wśród nich znajdują się zarówno dominujące $w$ jednym $\mathrm{z}$ typów tekstów, jak i występujące równomier- nie w różnych rodzajach tekstów. W analizie uwzględniony zostaje również udział w tekstach formy złożonej danego przymiotnika, żeby można było ocenić, na ile charakterystyczne jest występowanie formy krótkiej w danym tekście.

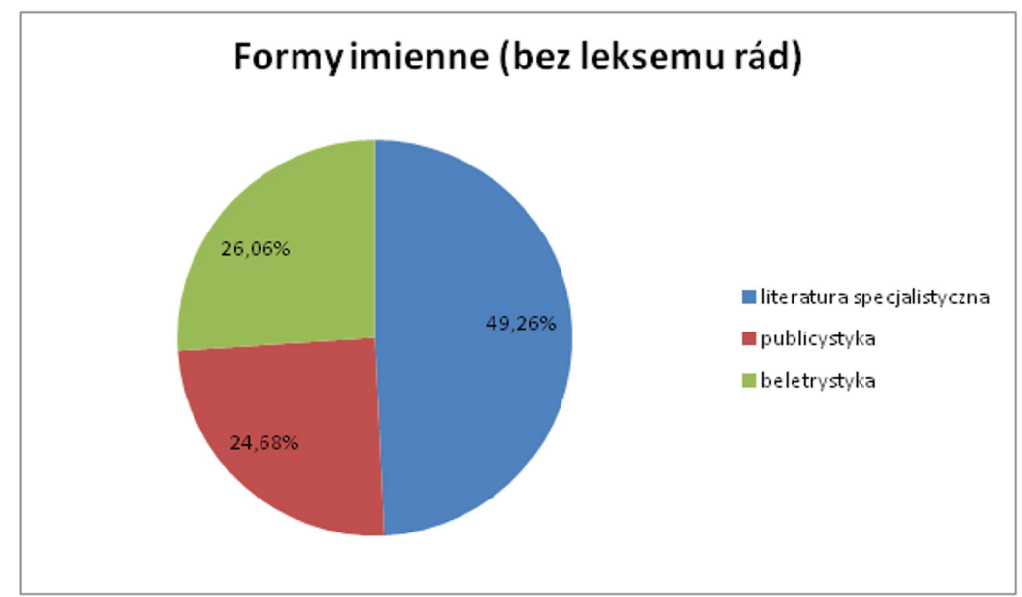

Rysunek 3. Występowanie form imiennych w tekstach

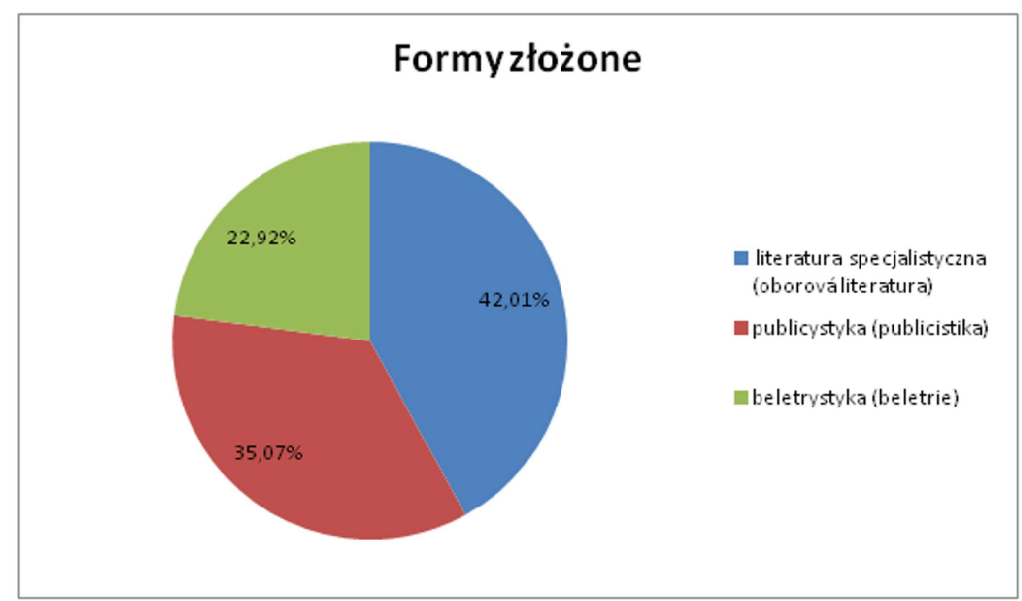

Rysunek 4. Występowanie form złożonych w tekstach 
Jak już zostało wspomniane z ogólnej statystyki wynika, że krótkie formy występują częściej w literaturze specjalistycznej, rzadziej w beletrystyce, a najrzadziej - w publicystyce. Wiele jednak zależy od charakteru samego przymiotnika oraz jego właściwości, co powoduje różnorodność rozkładania się postaci imiennych w tekstach. W tej części artykułu na przykładzie kilku często występujących przymiotników postaram się oddać tę skomplikowaną kwestię. Zacznijmy od przymiotnika vědom, którego udział formy krótkiej w tekstach odpowiada ogólnej statystyce. Jest to jednak spowodowane charakterem leksemu, a nie jego postacią imienną. Forma zaimkowa bowiem charakteryzuje się podobnym rozkładem w tekstach. Wysoce frekwentowana postać imienna schopen jest również typowa dla literatury specjalistycznej, przy czym i w tym wypadku forma długa dominuje w tym typie tekstu. Bardziej znamienny może być natomiast fakt, że mniejszy udział postaci imiennej znajdziemy w publicystyce, a następnie - w beletrystyce. Występowanie formy długiej, schopný, natomiast jest wyższe w beletrystyce niż w publicystyce. Wybór formy imiennej, często stosowanej w konstrukcjach: být schopen + bezokolicznik, przez osoby wypowiadające się na temat zdolności wykonania czegoś, jest podyktowany zarówno jego konfiguracją składniową, jak i jego literackim (również potocznie literackim) charakterem.

Měli jsme spoustu schůzek, se Slávou jsme mluvili. Ale nebyli jsme schopni protkat to s jeho prací na svazu a dalším fungováním X (2012): Sport, 24. 4. 2012

V souvislosti s jeho přípravou se město snaží vyřešit otázku tzv. brownfieldů, tedy zanedbaných území, na kterých se nacházejí zchátralé budovy, které již nebudou schopny plnit účel, který dříve měly. X (2013): Právo, 26. 2. 2013

Podobny rozkład postaci imiennej jest charakterystyczny dla przymiotnika nutný, z tym że udział form zaimkowych jest tu analogiczny. Przymiotnik ochoten natomiast występuje prawie w jednakowym stopniu w literaturze specjalistycznej i publicystyce, $\mathrm{z}$ minimalną przewagą w pierwszym z wymienionych typów tekstów. Forma długa natomiast jest charakterystyczna dla beletrystyki. Podobnie jak wcześniej omawiane przymiotniki: schopen, nutný, nie jest zarejestrowany w wypowiedziach nieliterackich a literackich książkowych i potocznie literackich. Przymiotnik možný natomiast ma największy udział w tekstach specjalistycznych (104 ipm.) oraz zbliżony poziom występowania w pozostałych typach tekstów (w publicystyce $-24 \mathrm{ipm}$., w beletrystyce $23 \mathrm{ipm}$.)

Jeszcze inaczej zachowuje się przymiotnik povinen, który jest typowy dla literatury specjalistycznej (36 ipm.), o wiele rzadziej występuje w publicystyce $(7,8$ ipm.) i beletrystyce $(2,88)$ przy czym jego odpowiednik o odmianie zaimkowej największy udział ma zarówno w literaturze specjalistycznej (46 ipm.), jak i w publicystyce (40 ipm.).

Część przymiotników imiennych występuje częściej w beletrystyce niż w innych typach tekstów, np. hotov, jist, mocen, zdráv, št’asten. Należy jednak wziąć pod uwage fakt, że z wymienionych tu przymiotników tylko postacie imienne hotov i zdráv mają największy udział w beletrystyce w przeciwieństwie do swoich długich odpowiedników. Jest to związane $\mathrm{z}$ tym, że przymiotnik zdráv występuje w większości poświadczeń w powitaniu bud' zdráv/zdráva, stąd jego dominacja w beletrystyce. Formy krótkie hotovo znajdują się nie tylko w rejestrach literackich, ale także nieliterakich, co też przesądza o jego udziale w tym typie tekstu.

Zdarza się jednak, że to właśnie publicystyka jest typem tekstu, w którym udział krótkich form jest najwyższy. Przykładem jest tu przymiotnik spokojen. Wiąże się to z tym, że przymiotnik ten również w długiej formie jest charakterystyczny dla tego typu tekstu. Oba występuja, w konstrukcjach: být spokojen s něčim, w tych samych kontekstach. Są zbliżone do siebie stylistycznie. Forma krótka nie znajduje się tu w wypowiedziach o silnym nacechowaniu nieliterackim. Najczęściej są to wypowiedzi związane ze sportem.

Jsem spokojený, hlavně že se splnil cíl, to ostatní je nad plán, navíc je to zásluha celého týmu. X (2012): Nymburský deník, č. 27/2012.

S výkonem jsem naprosto spokojen, hráli jsme tak, jak chceme. Chtěli jsme hrát perfektně odzadu, což se povedlo a nakonec $\mathrm{k}$ tomu přišly i branky, řekl trenér Libodřic Vladimír Pěkný. 
Różnica między postaciami krótkimi a długimi jest zauważalna natomiast w udziale tych form w beleterystyce i literaturze specjalistycznej. W beletrystyce forma spokojen ma mniejszy udział niż w literaturze specjalistycznej. Postać spokojený natomiast występuje częściej w beletrystyce niż w literaturze specjalistycznej. Koreluje to z faktem, że postać długą znajdziemy najczęściej we wspomnieniach, które są w korpusie SYN2015 zaliczone do literatury specjalistycznej, natomiast postać imienna jest charakterystyczna sensu stricte dla literatury profesjonalnej. Pod względem stylistycznym zatem forma krótka należy do rejestru książkowego i literackiego neutralnego i potocznego, natomiast postać długa obsługuje wszystkie rejestry stylistyczne.

„Ty vážně nedovedeš bejt spokojenej, co?” „Vypadá to, že ne”.

Torstensson byl se svými chlapy nadmíru spokojen, nebot' se „rvali jako lvi”. Englund, Peter (2000): Nepokojná léta. Překlad: Hartlová, Dagmar - Mandaus, Luděk. Praha: Nakladatelství Lidové noviny.

Byl jsem na štábu a měl u Reichsführera soukromé slyšení. Probíhalo jako obvykle: s naší prací není vůbec spokojen, chápeš, vůbec ! Tučková, Kateřina (2012): Žítkovské bohyně. Brno: Host.

Reasumując, udział poszczególnych form imiennych w tekstach nie zawsze jest czynnikiem istotnym. Należy tu wziąć pod uwagę występowanie całego leksemu z jego formami krótkimi i długimi, jego dystrybucję w konstrukcjach składniowych, połączeniach językowych itp. Pomocna jest tu również analiza stylistyczna wypowiedzi, z której wynika, że formy imienne w większości przypadków są typowe dla rejestru książkowego oraz literackiego neutralnego i potocznie literackiego. Nie jest natomiast obecna w czeszczyźnie nieliterackiej w przeciwieństwie do postaci długiej. Wyjątkiem jest tu forma a hotovo, znajdująca się także w wypowiedziach nieliterackich.

Zupełnie inny charakter ma przymiotnik rád. Jego zastosowanie jest bardzo szerokie. Typowym rodzajem testów, w którym się znajduje jest beletrystyka i publicystyka. Najrzadziej natomiast występuje w literaturze specjalistycznej. Nie jest też typowa dla rejestru książkowego, a raczej dla nieliterackiego oraz literackiego potocznego.

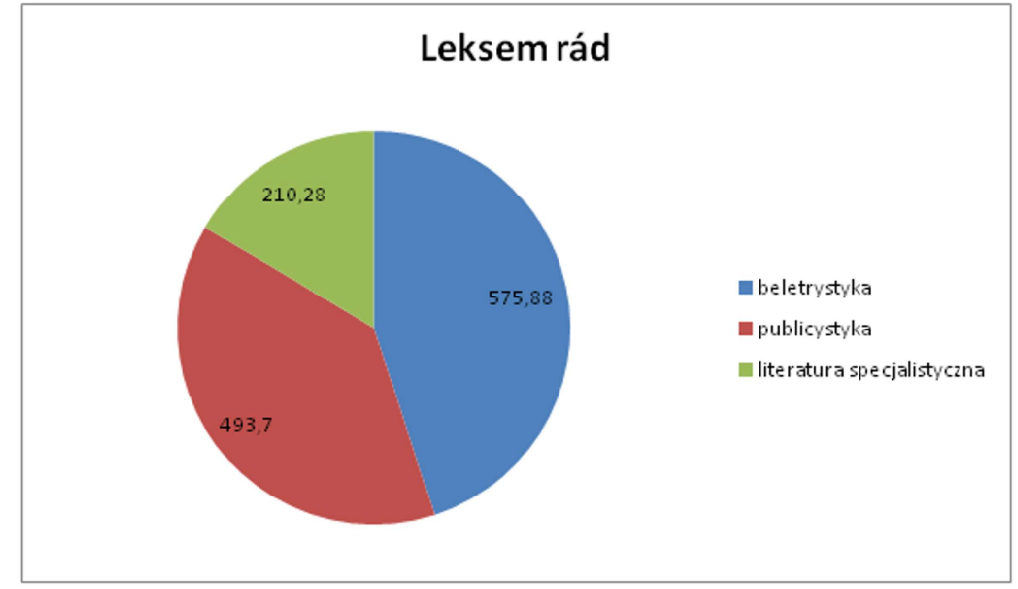

Rysunek 5. Występowanie w tekstach przymiotnika rád w korpusie referencyjnym SYN2015 (w wartościach ipm.)

\section{Występowanie przymiotników imiennych w konstrukcjach gramatycznych w świetle danych korpusowych}

Badanie korpusowe $\mathrm{z}$ jednej strony potwierdzają informacje zawarte w literaturze przedmiotu, o tym, że przymiotniki imienne występują $\mathrm{w}$ funkcji orzecznika i predykatywu, $\mathrm{z}$ drugiej strony natomiast dostarczają szczegółowszych informacji o funkcjach składniowych tej części mowy oraz konstrukcjach gramatyczno-leksykalnych, w których wystepują. Pierwszym wnioskiem, który się nasuwa jest ograniczenie konstrukcyjne form imiennych w porównaniu $\mathrm{z}$ formami złożonymi. Ze statystyki ogólnej wynika, że przymiotniki imienne pojawiają się przede wszystkim w orzeczniku i predykatywie, choć zdarzają się także wystapienia $\mathrm{w}$ funkcji przydawki niekongruentnej i okolicznika. Formy imienne łączą się również w sposób bardziej ograniczony z konkretnymi formami leksemów.

Najczęstsze konstrukcje, w których pojawiają się formy imienne, to $\mathrm{w}$ najprostszej formie połaczenie przymiotnika imiennego $\mathrm{z}$ bezokolicznikiem: 
být + przymiotnik imienny + bezokolicznik,

w konstrukcjach bardziej rozwiniętych - z innymi leksemami, np.:

být + przymiotnik imienny + przysłówek + bezokolicznik.

Warto zaznaczyć, że wyniki statystyczne tych konstrukcji są związane z kilkoma przymiotnikami imiennymi, które pod względem częstości plasują się wysoko. Są to m.in. schopen, možný, nutný, známý, ochoten, povinný, patrný, dlužný, hotový, hoden, mocen.

Nie we wszystkich przypadkach forma imienna jest swoista wyłącznie dla niej. Niemniej jednak jest spora liczba przymiotników, w których właśnie forma imienna przybiera częściej konstrukcje bezokolicznikową. Dobrym przykładem jest przymiotnik schopen, który występuje o wiele cześciej w funkcji orzecznika w konstrukcji bezokolicznikowej niż jego odpowiednik o odmianie złożonej, dla którego najczęstszą funkcją jest przydawka kongruentna, np.

Byl schopen dokonale zachytit omezené lidské typy, které jsou nevyčerpatelným zdrojem humoru.

Z wymienionych tu przymiotników bez względu na postać $\mathrm{z}$ bezokolicznikiem łączyć się będą: možno/možné. Forma imienna nie występuje w funkcji orzecznika w konstrukcji z bezokolicznikiem częściej niż jej odpowiednik. Warto zaznaczyć, że także listy czasowników łączących się z bezokolicznikiem są do siebie zbliżone, por.

je možno použít, využít, získat, dosáhnout, označit, najít, nalézt, nazvat, provést, vyjádřit;

je možné použít, využít, získat, najít, dosáhnout, provést, nalézt, zakoupit, vytvořit, nastavit.

Podobnie zachowuje się leksem nutný. Obie formy łączą się z bezokolicznikiem, a listy leksemów wypełniających to miejsce, są również do siebie zbliżone.

je nutno dodat, podotknout, přiznat, poznamenat, zdůraznit, provést, zmínit, upozornit, použít, uznat; je nutné zajistit, použít, provést, zmínit, zdůraznit, udělat, vzít, podotknout, dodat, uvést, dodržet, připomenout, upozornit, vytvořit, zvolit, zadat.

Podobnie te same połączenia leksykalne korpus rejestruje w przypadku form ochoten/ochotný.

Ciekawe jest to, że przymiotniki te mogą być wymiennie używane w tym samym tekście. W książce zatytułowanej Sociokulturní adaptace malých měst połączenia ochoten rekvalifikovat i ochotný rekvalifikovat występują 8 razy, z czego 6 razy w formie krótkiej, 2 razy w postaci długiej. Poświadczenia te nie różnią się między sobą, np.

Dvě třetiny jsou $\mathrm{v}$ případě, že by nenašly vhodné uplatnění se svou stávající kvalifikací, ochotny se na práci v obchodě, službách nebo cestovním ruchu rekvalifikovat, přičemž třetina je ochotná se rekvalifikovat určitě. Kromě těch, jichž se rekvalifikace netýká, neni ochotna se na práci v terciéru rekvalifikovat jen asi desetina obyvatel. Ochota rekvalifikovat se na práci v terciéru souvisí s věkem.

Inną konstrukcją, w której często pojawiają się formy imienne, jest struktura:

být + przymiotnik imienny + rzeczownik w dopełniaczu,

rzadziej w narzędniku czy celowniku oraz w innych przypadkach,

np. být hotov něčeho, být mocen nečeho, být pln něčeho, být si vědom něčeho, být vděčen někomu, být spokojen $\mathrm{s}$ něčím, být si jist něčím.

W niektórych połaczeniach przymiotniki imienne wysteppuja w innych funkcjach niż w orzeczniku, a mianowicie w funkcji przydawki niekongruentnej czy okoliczniku. Nieraz pełnią funkcję samodzielnego członu.

Z konstrukcji nieorzecznikowych warto opisać przymiotnik bos, łączący się częściej z czasownikami ruchu, np. běhat, chodit, jit, kráčet, odejít niż z czasownikiem být.

Zašpásoval jsem a ty všechny potvory, kromě té mučenky, prohlásily, že by za mnou šly bosy až do Prahy...

S nevinností malého nemluvněte a lehounkou bezstarostností, jako bych běžel bos trávou, jsem stále více zkracoval vzdálenost mezi námi dvěma. Abe, Kóbó (2008): Tvář toho druhého. Překlad: Winkelhöferová, Vlasta. Praha: Odeon. 
Innym przykładem mogą być struktury zawierające czasownik cítit oraz formę imienną przymiotników.

Karzáí se cítí osamocen Během včerejšího útoku se do ohrožení života dostali kromě jiných i školáci a novináři . X (2013): Lidové noviny, 26. 6. 2013.

\section{Występowanie przymiotników imiennych w stałych połączeniach językowych i kolokacjach w świetle danych korpusowych}

Część przymiotników imiennych występuje w ustalonych/charakterystycznych połączeniach językowych. Do takich przymiotników należą, m.in. zdráv, jist, hotov, možno, laskav.

$\mathrm{Z}$ danych korpusowych wynika, że pierwszy $\mathrm{z}$ omawianych tu przymiotników najczęściej występuje w połączeniach bud'zdráv, než je zdrávo, živ a zdráv.

Bud'te zdráv, velice zdráv" Malír jen pokyvoval hlavou a zahaloval se cigaretovým dýmem. Kundera, Ludvík (1999): Napospas. Brno: Atlantis.

Odhaduje se, že až 60 procent domácích mazlíčků má větší hmotnost, než je zdrávo . X (2010): Fajn život, č. 9/2010.

"Byl jsem št’astný, že jsem se s nimi znovu setkal a že jsou všichni živi a zdrávi." A měl jsem radost, že jim mohu říct, co pro mě to léto na jejich statku znamenalo vždyt' právě tehdy jsem pochopil, že Židé a Palestinci mohou tvořit jednu rodinu. Abuelaish, Izzeldin (2014): Nebudu nenávidět. Překlad: Neradová, Martina. Brno: Host.

Podobnie przymiotnik laskavý występuje najczęściej w połączeniu být tak laskav, np. bud' te tak laskav. Przysłówek ten jest nieraz wymieniany na inne, np. velmi, natolik.

Bud'te tak laskav a dolejte tam petrolej. Kuttner, Henry (2001): Čarovný svět Henry Kuttnera. Překlad: Medek, Pavel (et al.). Praha: Albatros.

Charakterystycznym połączeniem zawierającym formę krótką jest również powiedzenie je/bylo/není, nebylo hotovo lub samodzielne a hotovo. Występuje częściej niż jego odpowiednik je hotové. Warto zaznaczyć, forma hotovo konkuruje z nieliteracką postacią hotový nawet w wypowiedziach substandardowych.

„Neexistuje žádnej přesnej způsob,” řkekne, „To člověk ví a hotovo. Některý jsou Židi a ostatní to vědí.” „Pak ho něco napadne, oči se mu na okamžik rozzáríi." „A samozřejmě se to dá poznat z prŕjmení.” Giordano, Paolo (2013): Tělo. Překlad: Flemrová, Alice. Praha: Odeon.

Następnym połączeniem częściej występującym właśnie w postaci imiennej niż złożonej jest powiedzenie pokud možno. Połączenie to stanowi jedną szóstą poświadczeń wystąpień formy možno.

K podstatnému posunu dochází po roce 1850 - do módy se dostává muž činu, pokud možno vybavený již zmiňovaným mohutným plnovousem. Komárek, Stanislav (2012): Muž jako evoluční inovace? Praha: Academia.

Wystąpienia form pokud možné należą do rzadkości, w tym wypadku mamy do czynienia z bardziej rozwiniętymi strukturami, np. pokud je to možné.

Tyto aktivity by měly být prováděny v epizodách nejméně 10 minut, a pokud je to možné, tak by měly být rozloženy do celého týdne . Frömel, Karel - Mitáš, Josef (2013): Pohybová aktivita české dospělé populace v kontextu podmínek prostředí. Olomouc: Univerzita Palackého.

Niektóre przymiotniki w zależności od formy krótkiej czy długiej łączą się z innymi wyrazami. Częściowo jest to wymuszone przez inne role składniowe. Za przykład mogą tu posłużyć leksemy: věrný i vinný. Przymiotnik věren występuje w znaczeniu przywiązany do kogoś/czegoś, oddany czemuś. Najczęściej kolokuje z wyrazami: prezdívka, poslání, tradice, zvyk, zásada, heslo, víra, Čechy, československý, církev, zůstat, zůstávat. Tymczasem forma věrný występuje w większej liczbie znaczeń: zgodny z oryginałem, oddany komuś, postępujący zgodnie z zasadami. Najczęściej kolokuje z wyrazami kopie, oddaný, věrný, spojenec, zůstávat, služebník, fanoušek, replika, stoupenec, pritel itp.

Podobnie przymiotnik vinný łaczy sie cześciej z wyrazami związanymi z winem i winoroślą, np. réva, sklipek, sklep, shledat, hrozen, 
střik, natomiast forma vinen jest związana ze sprawami sądowymi, np. vinný, verdikt, obžalovaný, obžaloba, porotce, zločin, viník.

Innym ciekawym przykładem jest przymiotnik roven/rovný. Forma imienna łączy się najczęściej z liczbami i terminami matematycznymi být roven něčemu 'być równy czemuś'. Ważniejsze kolokaty to nula, součet, součin, mocnina, konstanta, objemový. Forma złożona natomiast kolokuje z następującymi leksemami dil, povrch, přiležitost, terén, zacházení, vlas, plocha, linie.

Podobnie postacie prítomen i prítomný rożnią się kolokacjami, co jest cześsciowo związane z innymi funkcjami, które pełnią w zdaniu. Krótka forma zatem występuje w połączeniach být přtomen $v$ něčem, $u$ něčeho, czyli $u$ výslechu, osobně, fyzicky, v minerále, křemeni. Forma złożona natomiast být duchem nepřitomný/nepřitomná, s nepř́tomným výrazem, seznamit prítomných.

\section{Podsumowanie}

Przymiotniki imienne znajdują sie pod względem statystycznym na marginesie języka czeskiego. Funkcjonują jednak w określonych konstrukcjach gramatycznych i leksykalnych, zajmując tym samym stałe miejsce w systemie czeszczyny. Ich zachowanie zależy od wielu czynników. Często jest to kwestia indywidualnego przymiotnika. Ze wspólnych cech można wymienić ich kwalifikację stylistyczną. Sa stosowane w wypowiedziach literackich, nie tylko książkowych, jak wskazują na to gramatyki języka czeskiego, ale także w potocznym języku literackim. W zależności od przymiotnika występują w różnego typu tekstach. Nie zawsze dominacja formy krótkiej w danym typie tekstu, jest znamienna dla tej właśnie postaci. Nieraz jest to kwestia charakteru przymiotnika bez względu na jego postać. Przymiotniki imienne najczęściej pełnią funkcję orzecznika lub predykatywu, rzadziej okolicznika, przydawki niekongruentnej lub członu samodzielnego. Konstrukcje, w których występują, są najczęściej ograniczone pod względem typu w przeciwieństwie do swoich odpowiedników złożonych. Część przymiotników imiennych jest także związana $\mathrm{z}$ ustalonym połączeniem językowym.

\section{Literatura}

B án k o Mirosław, 2002, Wyklady z polskiej fleksji, Warszawa: Wydawnictwo Naukowe PWN.

B artula Czesław, 1981, Podstawowe wiadomości z gramatyki staro-cerkiewno-słowiańskiej, Warszawa: Wydawnictwo Naukowe PWN

Mluvnice současné češtiny pod red. V. Cvrčka, 2010, Praha.

D a m b o r s ký Jiří, 1970, Podstawy gramatyki języka czeskiego, Warszawa: Państwowe Wydawnictwo Naukowe.

L a m p r e c h t Arnošt., Š 1 o s a r Dušan., B a u e r Jaroslav, 1986, Historická mluvnice češtiny, Praha: Státní pedagogické nakladatelství.

K o vá ř í k o vá Dominika, 2010, Př́davná jména (Adjektiva) w: Mluvnice současné češtiny Jak se píše a jak se mluví, red. Václav Cvrček, Karolinum Praha.

Mluvnice češtiny (2), 1986, ved. red. Jan Petr, Praha: Academia.

Nekula Marek, Rusínová Zdenka, Grepl Miroslav, Karlík Petr, 1995, Přriručni mluvnice češtiny, Brno.

Čechová Marie, Chloupek Jan, Krčmová Marie, Minářová Eva, 1997, Stylistika současné češtiny, Praha. 